Why has Wage Dispersion Grown in Mexico?

Is it the Incidence of Reforms or the

Growing Demand for Skills?

by

Michael Ian Cragg, Columbia University

Mario Epelbaum, CTAM

August 1995

1994-95 Discussion Paper Series No. 740

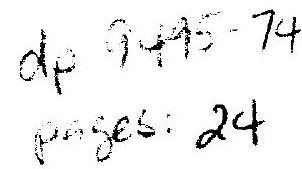




\title{
Why has Wage Dispersion Grown in Mexico? Is it the Incidence of Reforms or the Growing Demand for Skills?*
}

\author{
Michael Ian Cragg \\ Department of Economics, Columbia University \\ Mario Epelbaum \\ Centro de Investigacion Economica, ITAM
}

In the mid 1980s, Mexico undertook major trade reform, privatization and deregulation. This coincided with a rapid expansion in wages and employment that led to a rise in wage dispersion. This paper examines the role of industry and occupation-specific effects in explaining the growing dispersion. We find that despite the magnitude and pace of the reforms, industry-specific effects explain little of the rising wage dispersion. In contrast occupation-specific effects can explain almost half of the growing wage dispersion. Finally, we find that the economy became more skill-intensive and that this effect was larger for the traded sector because this sector experienced much smaller low-skilled employment growth. We therefore suggest that competition from imports had an important role in the fall of the relative demand for less-skilled workers.

*We thank John Ameriks, Francisco Gutierrez and Joelle Saad for their valuable help. We also appreciate the commentary of Alejandro Hernandez, Dani Roderick, Manuel Santos and the workshop participants at the NBER, Columbia, ITAM, UCLA, UBC and the Fifth Annual Canadian Labor Conference. The project received funding by the Centro de Investigacion Economica, ITAM and the Office of the Provost at Columbia University. 


\section{Introduction}

In the early eighties Mexico entered a severe economic crisis which forced the country's leadership to rethink its approach to government. Since then the Mexican economy has experienced a period of profound change: a wide and deep commercial opening to trade and foreign investment; the privatization of many state-owned enterprises; major tax reform; deregulation of industry; the creation of an independent central bank; and accelerated infra-structure construction with private funding.

These reforms coincided with dramatic changes in the Mexican urban labor markets. During the 1987-1993 period average real wages and employment grew by 30 percent and 22 percent respectively. These changes were accompanied by a dramatic increase in wage inequality across and within education and experience groups. Workers with post-secondary education and more experience saw their wages rise rapidly while less skilled workers experienced only slight wage growth. Cragg and Epelbaum (1995) document these changes and show that a major source of the rising inequality is a skill-biased demand shift rather than uniform demand growth in the face of differential supply elasticities.

At least four competing theories can explain the rise in the college premium in Mexico. The first is that reallocation or dissipation of rents affect unskilled labor disproportionately. The second is that institutional change can create new opportunities for managers, entrepreneurs and others who catalyze change during periods of transformation. In the face of slower supply growth, a premium is paid to such workers. The third is that shifts in the relative demand for products produced with different factor intensities generated wage dispersion. A familiar version of this theory is factor price equalization in the context of freer trade. An alternative version is a shift in government spending. The final theory is that the rising college premium is the result of a special relationship between capital and skilled labor. Different versions of this theory include technological change favoring skilled labor or a complimentarity between capital and skilled labor in an environment where capital is becoming cheaper.

Existing research has shown the importance of the capital related theory. Using household level data Cragg and Epelbaum (1995), show that by-industry input utilization in Mexico is inconsistent with a production function that aggregates labor. They claim this implies that capital must have a different relationship with different types of labor (for instance, capital and skilled labor are complements while capital and unskilled labor are substitutes). Using plant level data, 
Bernard (1995) and Ravenga (1994) show that more capital-intensive plants hire a higher proportion of skilled workers and offer higher wages. However, given the magnitude of the reforms, it is unlikely that capital-based stories are the sole cause of rising wage dispersion. Using household based data, Feliciano (1993) finds evidence that the industries that experienced larger openings to trade had a higher proportion of unskilled workers and experienced a reduction in their wage premium.

Much work still needs to be done in order to understand the nature and causes of wage dispersion in Mexico. Little is known about whether rent dissipation through privatization and deregulation plays a large role in generating wage dispersion. Furthermore, it is unknown what types of skills are in demand. Surely, occupation and industry-specific skills are correlated with general education and therefore, rising education returns may simply reflect rapid growth in a small number of occupations and industries. This paper uses household level data to assess the importance of rent dissipation, to identify the types of skills that are receiving increasing returns and to identify other forces behind the rising demand for skills. We first investigate whether the increases in returns to education are associated with particular tasks related to occupations or industries, or if they remain as returns to general education. Our method calculates the returns to education and experience, controlling for industry and occupation. We find that portable skills that are associated with a particular task, can explain about half of the growth in the return to education. The rest appears to be a rise in the return to general education that is unrelated to particular industries. We also find that industry dummies have little explanatory power and that there is little evidence of consistent increases or decreases in particular industry premia. Therefore, our finding that task-specific and not industry-specific skills are responsible for about one half of the wage dispersion across education groups supports the theory that catalyzers of change are receiving returns. This theory is supported by the fact that managers and professionals received, by far, the largest wage increases.

We then examine employment and wage patterns by industry and occupation to provide further insight into the forces behind the rising demand for skills. The employment patterns reveal a general skill intensification in the economy: the proportion of skilled labor increased in almost all industries. Important differences appear across the traded and the nontraded sectors. While skilled labor employment is growing in both at approximately the same rate, unskilled employment is growing much more slowly in the traded sector. While technological change should influence all sectors, it is not clear why technology in the traded sector 
should necessitate a much larger shift in skill mix. Any complete explanation of the growing wage dispersion must explain this phenomenon. Perhaps domestic consumer goods face stronger competition from imports.

Industry dummies did not reduce the growth in wage dispersion, hence it is unlikely that industry effects are an important force behind the growing dispersion. However, although small in magnitude, there exists variation in wages across industries. Changes in industry wages are related to the degree to which protection was reduced, and to the level of unionization in a given industry.

This paper is organized by first describing the data and the broad changes in the labor market. In section 3, we examine changes in the industry-specific and general occupation-related wage premia. In section 4 we examine the sources for industry-specific returns and then offer conclusions.

\section{The Data}

We use micro-level data from the Encuesta de Empleo Urbano collected by the Instituto Nacional de Estadistica Geografia e Informatica (INEGI). This data set contains quarterly wage and employment data on nearly one million workers over the last seven years. The data are representative of the sixteen largest urban areas in Mexico which account for about a third of the population. ${ }^{1}$ Similar to the U.S. Current Population Surveys, the data are from household surveys which fully describe family composition, human capital acquisition, and experiences in the labor market. Our data are drawn from 28 consecutive quarterly wage and employment surveys collected by the INEGI over $1 / 1987$ to $4 / 1993$. In person interviews are conducted in five consecutive quarters for each of approximately 50,000 households. Wage and employment data are collected for the week before the survey date. The sample includes only full-time workers who work for an officially registered firm for over 30 hours a week during the entire year. We chose not to incorporate the self-employed and seasonal workers in order to focus on the formal or mainstream labor market and to avoid problems with dealing with retained earnings.

The data contain a monthly earnings variable from which we calculate hourly wages as the ratio of monthly earnings to $4.3^{*}$ weekly-hours. For individuals who report their wages as a multiple of the minimum wage, we assign as their wage

\footnotetext{
${ }^{1}$ Approximately 70 percent of Mexico's population lives in an urban area. Moreover demographic and labor market conditions are very different across the urban and rural sectors so the results of this paper must be considered with this in mind.
} 
the mean of the interval. Wages are deflated by the national quarterly CPI to the first quarter of 1987.

Urban labor market trends are impressive: average wages rose $30 \%$ and full time employment rose around $21 \%$. To control for compositional changes we divide the sample into three education categories which are labelled primary, secondary and post-secondary. The secondary label corresponds to anyone with between nine to twelve years of schooling and the primary and post-secondary have more or less. We also create five experience groups divided into eight year intervals where potential experience is calculated by subtracting years of schooling plus six from the age variable. Although, the population has become relatively older and more educated these changes do not account for the rise in average wages. The structure of wages has changed.

Mexico has experienced a widening wage gap as the return to skills has risen within and across skill groups. The first column of Table 1 shows the basic facts for Mexico. First, the age-experience profile has shifted up between 5 and 20 percent for the least educated. Second, for those with a secondary. school education the average wage has increased 15 percent and the age experience profile has tilted so that in 1993 older workers earn 165 percent of younger workers' wages - an increase of 10 percent over the 1987 multiple of 153 percent. Third, those with some post-secondary schooling found that their average wage increased by 70 percent. This was combined with a significant rise in the returns to experience as the oldest workers with some post-secondary schooling saw their real wages double in a 7-year period. Finally, for the most educated the majority of this wage growth is in the upper-half of the wage distribution. Using a data set similar to the U.S. Current Population Survey, our finding of rising wage dispersion within and across skill classes is consistent with those found using survey data of only manufacturing plants (Revenga (1994), Feenstra and Hanson (1994), Hanson and Harrison (1994) and Bernard (1995), however we cover a larger portion of the population and have a more accurate measure of skill.

\section{Returns to occupation and industry-specific skills}

Wage dispersion in developing dualistic economies like Mexico will probably arise when there is sustained growth. Low-skill workers having high employment in the informal or rural subsistence economy relative to the higher paying urban formal sector, makes unskilled labor supply very elastic. On the other hand, skilled labor is scarce and thus its supply is inelastic. Simply if demand for 
labor expands uniformly across skill classes, wage dispersion is likely to occur. Cragg and Epelbaum (1995) show that the wage dispersion in Mexico cannot be explained solely by uniform labor demand growth. Rather demand for skilled labor must have grown faster. In this section we explore whether the skills in higher demand are industry-specific, task specific, or simply general education.

We measure task specific skills using occupation dummies and we measure industry-specific skills with a set of industry dummies. The reason that wages vary across occupations is that an occupation classification, like an education class, clearly embodies a bundle of skills. However, the reason behind the variation in wages across industries is not fully understood (see Moll (1993) and Krueger and Summers (1988)). We classify the competing explanations into four groups. First, in some industries the work is more dangerous or unpleasant and thus workers must be paid a compensating differential. The second type of explanation is related to workers' skills: in some industries workers acquire more industryspecific skills or the work requires more ability or effort for the same level of schooling and experience. The third type of explanation is related to rent sharing: some industries enjoy more rents which they must share with their workers. And finally, industry-specific returns may reflect spurious correlation with an omitted variable like tenure. If tenure varies across industry and if tenure is omitted from the regression, an industry premia is partially a reflection of tenure and not an industry effect ${ }^{2}$. This is an important consideration given the wide variation in industry expansion rates.

To explore how the returns to skills are changing we pool our data over the 28 quarters and calculate the following real wage regression:

$$
w_{i}=\sum_{t=1987}^{1993} Y_{i t}\left\{D_{I i}^{\prime} \alpha_{I t}+D_{O i}^{\prime} \alpha_{O t}+\sum_{e=1}^{3} \operatorname{ed}_{e i}\left\{\beta_{e t}^{0}+\beta_{e t}^{1} \exp _{i}+\beta_{e t}^{2} \exp _{i}^{2}\right\}\right\}
$$

where $i$ indexes people, $Y_{i t}$ are time dummies indicating the year in the survey, $D_{I i}$ is a vector of 22 industry dummies, $D_{O i}$ is a vector of 17 occupation dummies. The age experience profile is a quadratic function of potential labor market experience, $\exp _{i}$, where $\mathrm{d}_{e i}$ are education dummies corresponding to primary, secondary or post-secondary schooling. We allow the wage-experience profile to shift across time and across education groups. We also allow industry and occupation dummies to shift over time. We use the estimates of $\alpha_{t}$ and $\beta_{t}$ from these

${ }^{2}$ Moll (1993) has a larger number of explainations, however we believe that they all fit within one of our four categories. 
regressions to "purge" the average wage trends of industry and occupation effects. Because we are interpreting industry and occupation as skills, we choose the omitted categories to be the lowest-skill industry or occupation. Retail trade is a good omitted category for our purposes because the individual skill requirements for employment in that industry are probably minimal in contrast to manufacturing and other more sophisticated service industries. This assumption is supported by the fact that as an industry, retail workers receive much lower wages than the average. Service employees are a good omitted category because they should have very low skills compared with other occupations. Evidence of this claim is that their average wage is much lower than the average in the economy. Retail workers' wages as a whole grew $30 \%$, and service employees' wages experienced no growth.

If the skill-biased wage growth is tempered when controlling for industry and when controlling for occupation, it suggests that both industry and occupation wage premia are measures of specific skills. Alternatively, if the skill-biased demand growth is enhanced when controlling for industry, it suggests that either the return to industry-specific skills is falling or that other industry effects, such as rent dissipation or changing tenure, are canceling the rise in the returns to industry-specific skills.

Table 2 reports the implied wages by education group first without controlling for any variables and then controlling for industry and occupation. ${ }^{3}$ The reported wages when controlling for industry are calculated from a regression which includes industry dummies which are not included in the calculation of the predicted wage. Two regressions are run, one where the industry premia are restricted to be the same for both education categories, no post-secondary schooling and post-secondary schooling and one permitting them to be different. Reported wages when controlling for industry reflect the average wages in the economy if all workers were employed in the omitted category, retail trade. The table illustrates that including industry dummies does not dramatically affect wage growth. This is emphasized by the fact that the industry dummies do a poor job in explaining further the variation in wages beyond that explained by the education and experience dummies. Notice the R-squared increases only two percentage points. Thus the observed wage growth is not substantially affected by industry effects. Therefore, it is unlikely that a large portion of the growing wage dispersion is a function of rent dissipation, changes in the value of industry-specific skills or changes due to industry-specific reforms or industry-specific import competition.

\footnotetext{
${ }^{3}$ For the sake of brevity, the several hundred parameter estimates from each regression are omitted from the paper but are available from the authors upon request.
} 
Otherwise the industry dummies would have helped explain much more of the variation.

In order to remove dependence on the omitted category in our cross-time comparisons, in Table 3 we define a skill premium to education as the increase in wages over the primary schooling group, and in Table 4, we define a skill premium to experience as the increase in wages over entry level wages. In both tables, we normalize the differences by the economy wide average wage for each year. For 1993 , we calculate this average using the 1987 population weights so that in both 1987 and 1993, we use a comparable price per "hour of work for an average worker." Thus, when we discuss percent returns or increases, in percent returns these are relative to the economy-wide average wage.

Observe in Table 3 that controlling for industry marginally reduces the skill premium to education in both 1987 and 1993. This is consistent with the idea that the industry premia actually reflect some measure of skill or rents disproportionately accrued to the educated. However, the magnitude with which the premia are reduced is greater in 1987 than in 1993, thus industry effects actually increase the amount of wage dispersion from 1987 to 1993 . This suggests that some rents (or industry-specific returns) have been dissipated.

When we permit the industry premia to vary for those with post-secondary education the results change a little. In this case growth in the education premia is slightly reduced. However it is because the premia in 1987 is larger while that in 1993 remains the same, making it less likely that this represents an increase in the returns to industry-specific skills. Still industry effects, whether they represent rents, skills or changing tenure, are minor and thus relatively unimportant.

Table 4 shows that the industry effects have mixed effects on the return to experience. For the primary schooling group it lowers the return to experience at all levels and for the other two education groups, it lowers the return to experience early on but it raises it for the later years. This effect is more pronounced in 1987. This implies either that experienced workers were most affected by industry correlated shocks such as reforms and opening to trade, or by industry, this category experienced the largest fall in unmeasured tenure. But again the industry effects are small. ${ }^{4}$

Including occupation dummies in the regression considerably reduces wage growth which means that occupation returns have been increasing rapidly. Tables

${ }^{4}$ Although the industry effects may be biased downwards due to measurement error, evidence against this argument is that the year-to-year correlation in the estimated industry coefficients ranges from 0.67 to 0.92 . 
2, 3 and 4 poignantly illustrate this point: the $\mathrm{R}$-squared increases by 8 percentage points; the growth in the education premia are reduced by 50 to 100 percent; and the growth in the returns to experience are considerably lower than those calculated with no controls. Thus task specific skills are an important source of the wage variation in the economy.

Table 5 presents employment and wage premia patterns by occupation. The premia are reported in 1987 new pesos and normalized the same way as the returns to education and experience in Tables 3 and 4 . The patterns reinforce the notion that a large part of the wage growth is due to increasing returns to occupations which a priori we would expect to be skill intensive. The workers with the highest occupation premia are those experiencing the most rapid rise in the value of their occupation specific skills. This is true for all education groups and more pronounced for workers with some post-secondary education.

Professionals and administrators, including public administrators received by far the largest wage increases (post-secondary transport workers also received an important rise in their wage premium but they represent a relatively small number of workers). This supports the theory that the rapid pace of change in the economy increased the demand for individuals that can enact change: managers and professionals. The supply of these workers is more restricted than that for less-skilled workers and thus shortages are created. The resulting scarcity of management skills in periods of rapid reform has been found in other settings. ${ }^{5}$

The employment and wage changes by occupation provide further evidence that labor supply elasticities play an important role in determining wage changes in Mexico. Occupations like service worker, salesperson and transport worker, which experienced large employment growth for less-educated workers are also occupations with slower growth in wage premia. The abundance of idle people who can do these jobs raises labor supply elasticities which keeps wages down in these occupations despite their rapid demand growth.

Like in the U.S., there appears to be an "hour-glassing" of employment in manufacturing: employment growth in both low- and high-skill manufacturing occupations is more rapid than in medium-skill occupations. While factory worker employment is stagnant, employment of factory helpers and industrial foremen is rapidly expanding. Factory helpers are even less skilled than factory workers so the large increase in their employments is somewhat of a puzzle. It may be a reclassification of jobs or a reflection of labor needs of new technologies. The large increase of industrial foremen is consistent with the findings of studies using

\footnotetext{
${ }^{5}$ See Dyck (1994) for a description of this phenomena in the newly unified Germany.
} 
plant level data that manufacturing is becoming more skill intensive. Thus, in manufacturing by occupation there is a divergence in skill intensification as on the one hand, the relative employment of very high-skill occupations increased and on the other hand, there is a relative increase in the employment of very low-skill occupations.

This section reveals two important changes in the attributes of the Mexican labor market. First, almost half the growth in the education premia is related to an increase in task or occupation specific skills which are portable across firms. We are unable to determine whether this rise is a function of increasing skill quality or simply a shortage of skills in the face of increasing demand. The second finding is that the remaining half of the rising education premia is not explained by the presence of industry-specific skills. This suggests that the return to industryspecific skills is not growing. We do not believe this is conclusive because it may be that other industry correlated shocks, such as changing tenure or shifting rents, are cancelling out the growing returns to skills. Hence the question remains: why is it that industry dummies do such a poor job in explaining wage variations in Mexico when they appear to be important in other countries (Moll (1993) and Krueger and Summers(1988)) In the next section we examine closer the relationships between industry wages and employment in order to identify some of the effects of trade liberalization and the other reforms.

\section{The Change in Industry Labor Markets}

As mentioned in the introduction, from the mid 1980s to early 1990s, the Mexican economy experienced a series of major reforms only one of which was trade liberalization. ${ }^{6}$ In this section, by industry we look at changes in employment and wages in order to assess the magnitude of the reform induced impacts.

Our conclusions are twofold. First it appears that the effects of opening trade to imports reduced the demand for low-skill labor in a significant manner. And second, confirming the results from the previous section, if rent dissipation and other reforms had an effect on wages it is small and, surprisingly, it has a tendency to reduce wage dispersion.

\footnotetext{
${ }^{6}$ For an excellent description of these reforms see Aspe (1993), Ten-Kate (1993) and Fernandez (1993).
} 


\subsection{Trade Related Industry Wage and Employment Changes}

The Mexican trade reforms are likely to have generated two separate trade impacts. The first effect is that as protection is reduced the cost of capital goods and intermediate goods falls. If skilled labor is a complement with capital, this raises the relative demand for skilled labor. However, there is no immediate reason why this effect should have a different impact on tradeables and nontradeables since both benefit from new technology and modern management practices.

The second effect is that as protection is reduced consumer goods from abroad flood the country exposing much of manufacturing to punishing competition. This accelerates the process of switching to more skill intensive technologies as many inefficient less-skill intensive producers go bankrupt. The peso appreciation after 1988 accentuates these two trade impacts. ${ }^{7}$

In Table 5, we report industry wages and employment disaggregated into the traded and nontraded sectors where there are two different education categories: those with and without a post-secondary education. Recall that the omitted category in the regressions generating the coefficients is retail trade and that the wage premia are reported in 1987 real pesos. The reported percentage wage change is the difference in the estimated 1993 and 1987 industry coefficients normalized by the average wage in 1987 . The ${ }^{* *}$ and ${ }^{*}$ denote that this percentage change is significantly different from zero at the $5 \%$ and $10 \%$ level of significance respectively.

Roughly speaking one-third of employment is in the less-skill intensive traded manufacturing industries. In 1987, 13.2 percent of workers in traded industries and 19.6 percent of nontraded workers had a post-secondary education. From 1987 to 1993 , in both the traded and nontraded industries, skilled worker employment grew 30 percent. Employment growth for lower-skilled workers, however, was much lower in the traded industries than in the nontraded industries: 7 percent in nontraded industries and 22 percent in traded industries. Thus, while the traded sector is becoming more skill intensive than the nontraded sector, employment in that sector is growing at a slower rate.

Although the finding that traded industries are growing and becoming more skill intensive is consistent with findings using plant level data (Bernard (1995)), the manufacturing data is somewhat misleading. First, the manufacturing sector employment is smaller and growing at a slower rate than nonmanufacturing sec-

\footnotetext{
${ }^{7}$ Textiles, clothing and shoes were particularly hard hit and during the Peso Crisis in 1994. the administration responded by raising tariffs 30 percent for those product coming from all countries that did not have a free trade agreement with Mexico.
} 
tor and hence not representative of the changes in Mexico. Second, even though traded industries are becoming more skill intensive relative to nontraded, the reason is not more intensive hiring rates of skilled workers but rather less intensive hiring rates of less-skilled workers. Finally, manufacturing data is likely to understate the skill intensification in Mexico. When skills are measured by occupation specific attributes, we found that the fastest growing occupations for post-secondary educated workers are technical workers and industrial foremen, the very occupations most likely to be classified as production workers (i.e. "unskilled" in the plant level data). Our results suggest that studies using firm level data underestimate the size of the shift to skilled workers.

The small average increase in industry premia for unskilled workers combined with rapid employment growth suggests that no shortage of low-level industryspecific skills arose in either the traded or nontraded sector: except in construction and leather and shoe production there were no significant changes in the industry premia for workers with no post-secondary education. However, for skilled workers, relative to the nontraded sector, both the mean and the variance of the industry premia in the traded sector rose. This suggests that trade had differential effects across the manufacturing industries. On the one hand, industries producing textiles, leather and shoes experienced larger reductions in protection while at the same time their industry returns declined. On the other hand, industries producing processed metal goods, wood and paper products and chemicals, plastics and cement gained from freer trade as both the industry premia and employment increased. The difference between these two sets of industries is that the set of industries gaining from trade is the one more likely to have reaped the rewards of cheaper capital and intermediate goods while the set of industries losing from trade is the set likely to have suffered more from import competition.

\subsection{Nontrade Related Industry Effects}

Looking closer at industry wage patterns may reveal further evidence as to the causes of the growing wage dispersion. The challenge in doing this, however, is that as mentioned before industry changes reflect several economic effects and there are few degrees of freedom.

If industry premia in Mexico primarily represent compensating differentials for poor working conditions and such job related risks as injury or income variation. then despite the rapid changes in Mexico, the cross-time correlation in industry premia could be large. For low-skill workers, there is considerable stability in 
the pattern of industry wage differentials: the correlation between year-to-year industry premia ranges from 0.8 to 0.9 . This pattern is not observed for workers with some post-secondary schooling. From 1987 to 1993, the year-to-year correlation in industry premia for post-secondary trained workers ranges from -0.07 to 0.27 . Furthermore, there is no stable pattern in the correlation of industry premia between high-skill and low-skill. The stable industry wage premia for less-skilled workers is evidence that an important component of the industry wage premia represents compensating differentials. However, the premia are very small.

If industry wage premia represent returns to industry-specific skills we would expect that in rapidly expanding industries, the supply of the skills would become scarce and hence the industry wage would be bid up. A negative correlation between industry employment growth and growth in industry premia, would reject this hypothesis. For low-education workers, there is a positive correlation of 0.39 between the 1993-1987 percentage change in industry premia and percentage change in employment. For post-secondary trained workers, this correlation is small but negative -0.08 . Thus while the industry premia for lower educated workers could represent returns to industry-specific skills this does not appear to be the case for more educated workers. Hence it is unlikely that wage dispersion is a function of industry-specific stills.

Industry premia may reflect spurious correlation arising from an omitted variable like tenure which measures employer specific skills. In growing industries new hires will reduce the industry average level of tenure which would lead to a negative correlation between employment growth and changes in industry premia. This negative correlation is accentuated by shrinking industries with seniority rules where the average tenure would be rising as the workers who last joined firms are laid off. Therefore, the negative correlation between changes in employment and changes in industry premia for post-secondary workers may reflect changes in unobserved tenure.

An often cited cause of wage dispersion in the U.S. and Mexico is the diminishing power of unions. In Mexico, we find that unions are not located in industries where the low-skill workers receive higher wages, but are found in industries where the high-skill workers receive a wage premium. ${ }^{8}$ This may reflect unionization of industries with the highest potential for redistribution. Through time, in indus-

\footnotetext{
${ }^{8}$ Between 1987 and 1993 , we find that the degree of unionization is highly negatively correlated with the non-post-secondary industry premia (range is -0.75 to -0.45 ). In contrast there is a small but positive correlation between the degree of unionization and the post-secondary industry premia (range is 0.05 to 0.12 ).
} 
tries with higher unionization rates we find that low-skill workers have suffered a smaller decline in relative wages and a larger rise in employment. ${ }^{9}$ Together, these facts suggest that rent dissipation, due to a loss in union bargaining power, does, not seem to be a source of growing wage dispersion; to the contrary, low-skill workers in industries with low unionization rates appear to have suffered larger relative wage and employment losses.

In conclusion the industry wage differences for non-post-secondary educated workers are small and seem to represent compensating differentials. The industry wage premia for post-secondary educated workers are larger and more volatile. It is unlikely that they represent compensating differentials and it is difficult to determine whether they represent rents or industry-specific skills. The negative correlation between industry wage premia and employment growth for post-secondary educated workers suggests that tenure may be an important omitted variable. Finally, the weakening position of unions does not appear to have been a source of wage dispersion.

\section{Conclusion}

From 1987 to 1993, urban wages in Mexico became more dispersed, both within and across education and age groups. This finding would not be surprising in a dualistic economy with skill differentiated labor supply elasticities and uniform labor demand growth. However, previous research in Mexico suggests that in fact there was a skill-biased demand growth. This paper informs the Mexican wage debate by providing explanations for the skill-biased shift in wages, using household level data to examine how wage and employment changes differed across industries and occupations during the reform period.

We found that the return to occupation explains close to half of the growing wage dispersion. Workers in the highest paid occupations have experienced the largest wage growth. Similar to other transition economies, the supply of managers and professionals is restricted precisely when their skills are most required. Further evidence of the importance of labor supply elasticities in equilibrium wage outcomes is the fact that low-skill occupations, such as service worker, salesperson and transport worker, experienced rapid employment growth but sluggish wage

\footnotetext{
${ }^{9}$ The 1987-1993 change in industry wages and employment for non-post-secondary workers is positively correlated with the degree of unionization ( 0.50 and 0.70 repsectively) but is uncorrelated for the post-secondary industry wage changes.
} 
growth. Rising wages in occupations requiring more sophisticated, task-specific skills clearly indicate that the demand for skills in Mexico has risen rapidly.

We were surprised to find that industry effects had little explanatory power, accounted for little of the rising wage dispersion and showed only weak patterns across industries with common characteristics. This suggests that reform-induced rent dissipation is a less important source of wage change than the overall demand growth for general and occupation specific skills. Still, some of the industry patterns are interesting. Low-skilled workers have small but very stable industry premia, suggesting the importance of compensating differentials for industry conditions. In contrast, high-skill workers showed large variations in wage and employment growth across industries. Future work on the industry structure of the labor market would benefit by measuring tenure.

Finally, we also found that Mexico experienced a general skill intensification in both the nontraded services sector and the traded manufacturing sector. While high-skill employment grew at the same rate for both sectors, low-skill employment grew much more slowly in the traded sector. Although the finding that traded industries were growing and becoming more skill-intensive is consistent with research using manufacturing plant level data, the manufacturing data is somewhat misleading. Manufacturing data understate the skill intensification in Mexico and, by omitting the larger and more skill-intensive services sector gives an inaccurate picture of the changes in the Mexican labor market over the reform period.

Mexico's rejection of import substitution policies is likely to have inspired an import catalyzed technological change. While technology is probably an important factor that influenced all sectors, it is unclear why technology in the traded sector would necessitate a much larger shift in skill mix. Hence, any complete explanation of the growing wage dispersion in Mexico must account for the higher skill intensification in manufacturing due to slower low-skill employment growth. We posit that this may arise from competition from imported final goods, which intensified the rate of technology adoption and lowered the demand for low-skill workers in manufacturing. 


\section{Bibliography}

\section{References}

Aitken, Brian, Gordon H. Hanson, Anne E. Harrison (1994). "Spillovers, Foreign Investment, and Export Behavior," mimeo.

Aspe, Pedro (1993). Economic Transformation: The Mexican Way, MIT Press.

Bernard, Andrew (1995). "Exporters and Trade Liberalization in Mexico: Production Structure and Performance," mimeo.

Dyck, I.J. Alexander (1995). "Privatization in Eastern Germany: Management Selection and Economic Transition," Harvard Business School Working Paper \#95-030.

Feenstra, Robert C. and Gordon Hanson (1994). "Foreign Investment, Outsourcing and Relative Wages," mimeo.

Feliciano, Z. (1993). "Workers and Trade Liberalization: The Impact of Trade Reforms in Mexico on Wages and Employment," mimeo.

Fernandez, (1993). "Deregulation as a Source of Growth in Mexico," ITAM, mimeo.

Hanson, Gordon H. and Anne Harrison (1994). "Trade, Technology, and Wage Inequality: Evidence from Mexico," mimeo.

Krueger, Alan B. and Lawrence H. Summers (1987). "Efficiency Wages and the Inter-Industry Wage Structure," Econometrica 56, pp. 259-293.

Mincer, Jacob (1974). Schooling, Experience, and Earnings, New York: National Bureau of Economic Research.

Moll, Peter G. (1993). "Industry Wage Differentials and Efficiency Wages," Journal of Development Economics 41, pp. 213-246.

Revenga, A. (1994). "Employment and Wage Effects of Trade Liberalization: The Case of Mexican Manufacturing," mimeo. 
Ten Kate, A. (1993). "Trade Liberalization and Economic Stabilization in Mexico: Lessons of Experience," World Development, 20. 


\begin{tabular}{|c|c|c|c|}
\hline & 1987 & 1993 & \% Change \\
\hline Pinuary & 056 & 060 & 0.08 \\
\hline $0-8$ years experience & 0.45 & 0.47 & 0.05 \\
\hline $9-16$ years experience & 0.56 & 0.59 & 0.06 \\
\hline 17-24 years experience & 0.60 & 0.66 & 0.10 \\
\hline $25-32$ years experience & 0.61 & 0.68 & 0.10 \\
\hline 33-40 years experience & 0.59 & 0.71 & 0.20 \\
\hline 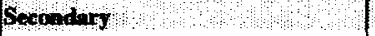 & 072 & 083 & 0,15 \\
\hline 0-8 years experience & 0.62 & 0.66 & 0.08 \\
\hline 9-16 years experience & 0.76 & 0.83 & 0.10 \\
\hline 17-24 years experience & 0.83 & 1.05 & 0.26 \\
\hline 25-32 years experience & 0.84 & 1.20 & 0.43 \\
\hline 33-40 years experience & 0.95 & 1.09 & 0.15 \\
\hline Tod secendops & 111 & 186 & 0.68 \\
\hline $0-8$ years experience & 0.95 & 1.34 & 0.42 \\
\hline 9-16 years experience & 1.18 & 1.90 & 0.61 \\
\hline 17-24 years experience & 1.29 & 2.31 & 0.79 \\
\hline 25-32 years experience & 1.23 & 2.45 & 0.99 \\
\hline $33-40$ years experience & 1.09 & 1.99 & 0.82 \\
\hline
\end{tabular}

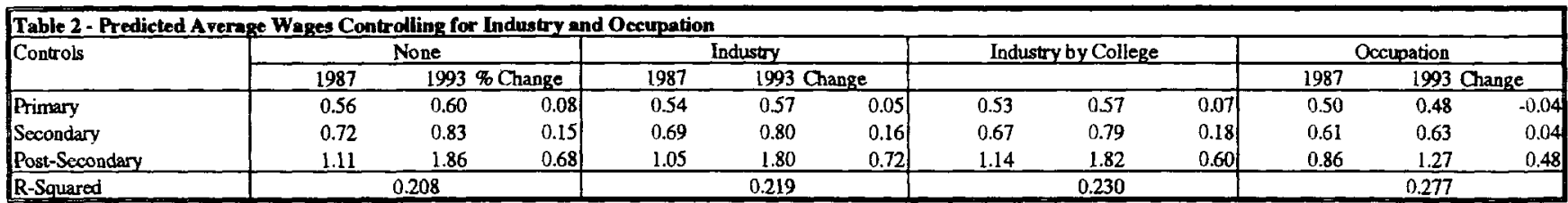

Predicted values are calculated from the regressions as indicated in Equation (1). Omitted categories are retail trade and service employee.

Third column is the percentage change from column 1 to column 2 .

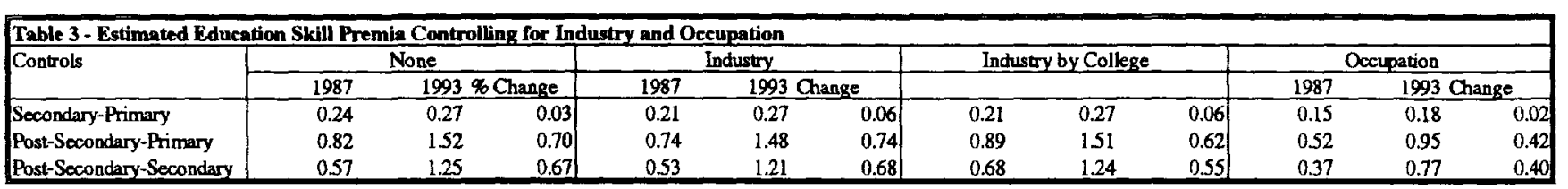

1 st and 2 nd column entries are the indicated difference between average predicted education returns.

Third column is the percentage difference between first and second columns.

\begin{tabular}{|c|c|c|c|c|c|c|c|c|c|c|c|c|}
\hline \multirow[t]{2}{*}{ Controls } & \multicolumn{3}{|c|}{ None } & \multicolumn{3}{|c|}{ Industry } & \multicolumn{3}{|c|}{ Industry by College } & \multicolumn{3}{|c|}{ Occupation } \\
\hline & 1987 & 1993 & $\%$ Change & 1987 & 1993 & & 1987 & 1993 & & 1987 & 1993 & \\
\hline \multicolumn{13}{|l|}{ Primary Relative to Entry } \\
\hline 9.16 years experience & 0.17 & 0.15 & -0.02 & 0.11 & 0.11 & 0.01 & 0.10 & 0.11 & 0.01 & 0.10 & 0.08 & -0.01 \\
\hline $17-24$ years experience & 0.22 & 0.22 & 0.00 & 0.18 & 0.21 & 0.02 & 0.18 & 0.20 & 0.02 & 0.17 & 0.15 & -0.02 \\
\hline $25-32$ years experience & 0.25 & 0.25 & 0.00 & 0.21 & 0.26 & 0.04 & 0.21 & 0.25 & 0.04 & 0.20 & 0.19 & -0.02 \\
\hline 33-40 years exparience. & 0.21 & 0.29 & 0.07 & 0.21 & 0.26 & 0.06 & 0.20 & 0.26 & 0.05 & 0.19 & 0.19 & 0.00 \\
\hline \multicolumn{13}{|l|}{ Secondary Relative to Entry } \\
\hline $9-16$ ycars experience & 0.21 & 0.20 & -0.01 & 0.16 & 0.22 & 0.06 & 0.16 & 0.22 & 0.06 & 0.13 & 0.15 & 0.01 \\
\hline 17-24 years experience & 0.32 & 0.46 & 0.14 & 0.30 & 0.45 & 0.15 & 0.29 & 0.44 & 0.15 & 0.24 & 0.30 & 0.06 \\
\hline $25-32$ years experience & 0.32 & 0.64 & 0.32 & 0.40 & 0.66 & 0.26 & 0.39 & 0.65 & 0.26 & 0.30 & 0.44 & 0.15 \\
\hline 33-40 years experiencel & 0.49 & 0.51 & 0.02 & 0.45 & 0.87 & 0.42 & 0.44 & 0.85 & 0.41 & 0.31 & 0.59 & 0.28 \\
\hline \multicolumn{13}{|c|}{ Post-Secondary Relative to Entry } \\
\hline 9-16 years experience & 0.34 & 0.67 & 0.33 & 0.28 & 0.73 & 0.45 & 0.28 & 0.73 & 0.46 & 0.21 & 0.50 & 0.29 \\
\hline 17-24 years experience & 0.51 & 1.16 & 0.65 & 0.46 & 1.17 & 0.71 & 0.46 & 1.18 & 0.72 & 0.33 & 0.78 & 0.45 \\
\hline 25.32 years experience & 0.41 & 1.33 & 0.92 & 0.52 & 1.29 & 0.77 & 0.52 & 1.30 & 0.78 & 0.36 & 0.84 & 0.47 \\
\hline 33-40 years experience & 0.21 & 0.78 & 0.56 & 0.46 & 1.09 & 0.63 & 0.47 & 1.10 & 0.63 & 0.29 & 0.65 & 0.36 \\
\hline
\end{tabular}

Ist and 2nd column entries are the difference between the av. predicted experience group indicated and the group with 0-8 years experience.

Third column is the percentage difference between first and second columns. 


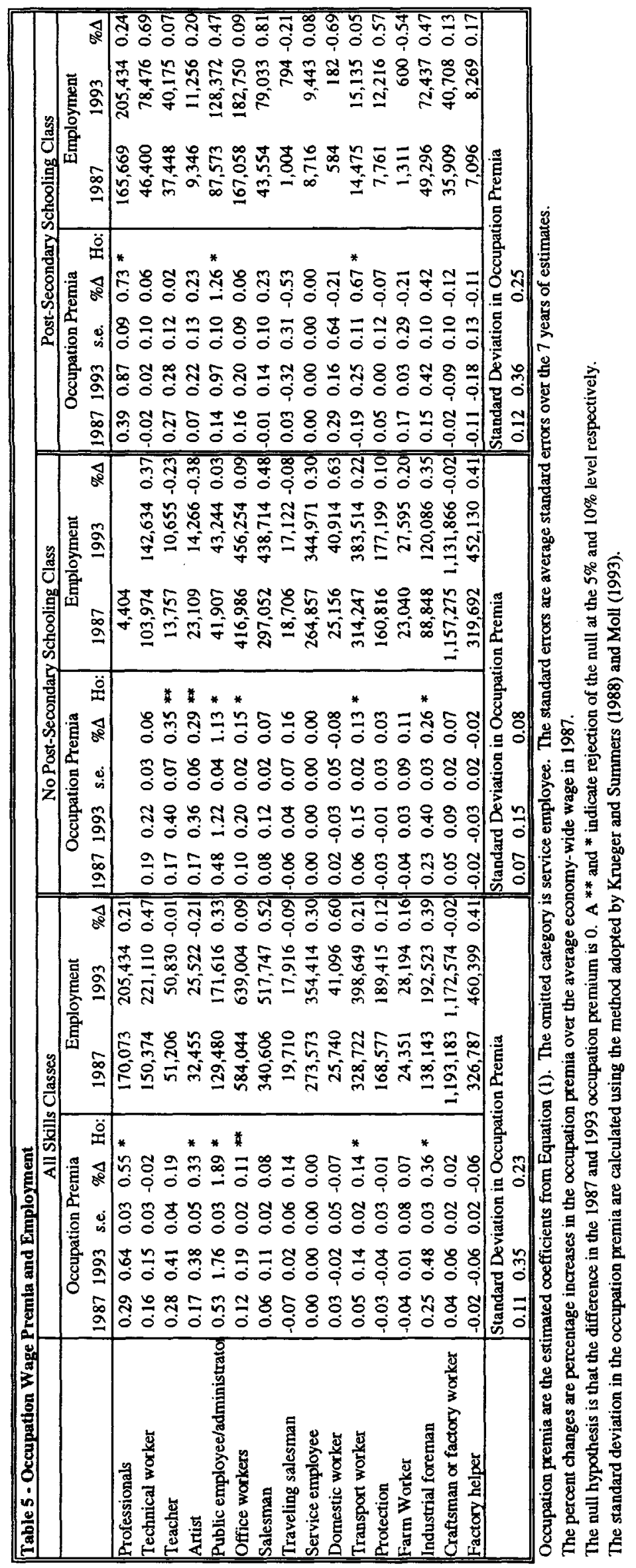




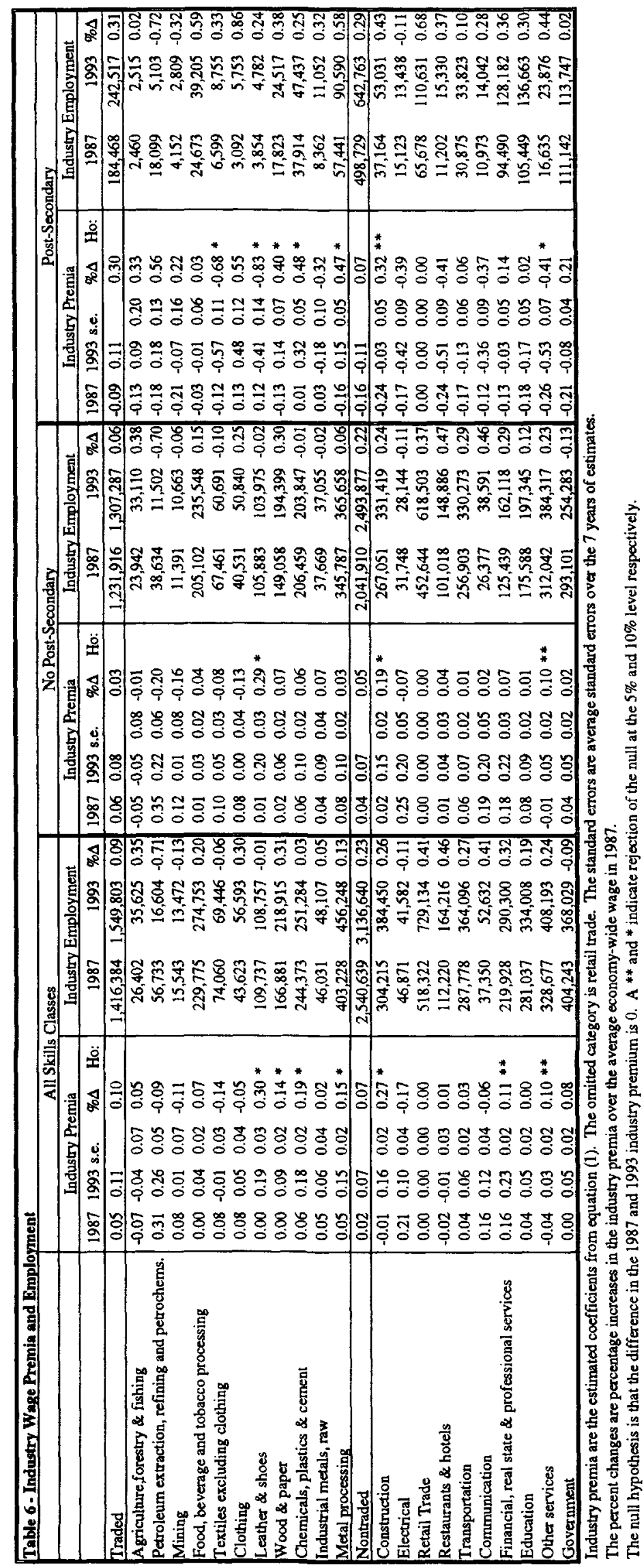




\section{4-1995 Discussion Paper Series}

Department of Economics

Columbia University

1022 International Affairs Bldg.

420 West 118 th Street

New York, N.Y., 10027

The following papers are published in the 1994-95 Columbia University Discussion Paper series which runs from early November to October 31 (Academic Year). Domestic orders for discussion papers are available for purchase at $\$ 8.00$ (US) each and $\$ 140.00$ (US) for the series. Foreign orders cost $\$ 10.00$ (US) for individual paper and $\$ 185.00$ for the series. To order discussion papers, please send your check or money order payable to Department of Economics, Columbia University to the above address. Be sure to include the series number for the paper when you place an order.

708. Trade and Wages: Choosing among Alternative Explanations

Jagdish Bhagwati

709. Dynamics of Canadian Welfare Participation

Garrey F. Barret, Michael I. Cragg

710. Much Ado About Nothing? Capital Market Reaction to Changes in Antitrust Precedent concerning Exclusive Territories.

Sherry A. Glied, Randall S. Kroszner

711. The Cost of Diabetes

Matthew Kahn

712. Evidence on Unobserved Polluter Abatement Effort

Matthew E. Kahn

713. The Premium for Skills: Evidence from Mexico

Michael Cragg

714. Measuring the Incentive to be Homeless

Michael Cragg, Mario Epelaum

715. The WTO: What Next?

Jagdish Bhagwati

716. Do Converters Facilitate the Transition to a New Incompatible Technology?

A Dynamic Analysis of Converters

Jay Phil Choi

716A. Shock Therapy and After: Prospects for Russian Reform Padma Desai

717. Wealth Effects, Distribution and The Theory of Organization -Andrew F. Newman and Patrick Legros 
1994-95 Discussion Paper Series

718. Trade and the Environment: Does Environmental Diversity Detract from the Case for Free Trade?

-Jagdish Bhagwati and T.N. Srinivasan (Yale Univ)

719. US Trade Policy: Successes and Failures

-Jagdish Bhagwati

720. Distribution of the Disinflation of Prices in 1990-91 Compared with Previous Business Cycles

-Philip Cagan

721. Consequences of Discretion in the Formation of Commodities Policy

-John McLaren

722. The Provision of (Two-Way) Converters in the Transition Process to a New Incompatible Technology

-Jay Pil Choi

723. Globalization, Sovereignty and Democracy

-Jagdish Bhagwati

724. Preemptive R\&D, Rent Dissipation and the "Leverage Theory"

-Jay Pil Choi

725. The WTO's Agenda: Environment and Labour Standards, Competition Policy and the Question of Regionalism

-Jagdish Bhagwati

726. US Trade Policy: The Infatuation with FTAs

-Jagdish Bhagwati

727. Democracy and Development: New Thinking on an Old Question

-Jagdish Bhagwati

728. The AIDS Epidemic and Economic Policy Analysis

-David E. Bloom, Ajay S. Mahal

729. Economics of the Generation and Management of Municipal Solid Waste

-David E. Bloom, David N. Beede

730. Does the AIDS Epidemic Really Threaten Economic Growth?

-David E. Bloom, Ajay S. Mahal

731. Big-City Governments

-Brendan O'Flaherty

732. International Public Opinion on the Environment

-David Bloom 
733. Is an Integrated Regional Labor Market Emerging in the East and Southeast Asia? -David Bloom, Waseem Noor

734. Migration, Integration and Development -Abhijit V. Banerjee, Andrew Newman

735. Infrastructure, Human Capital and International Trade -Ronald Findlay

736. Short Ballots: Why Mayors Are in Charge of So Many Different Things -Brendan O'Flaherty

737. Demand for Environmental Goods: Evidence from Voting Patterns on California Initiatives -Matthew Kahn and John Matsusaka

738. Inflation and Stabilization in Poland 1990 - 1995 -S.Wellisz

739. Particulate Pollution Trends in the 1980's -M. Kahn

740. Why has Wage Dispersion Grown in Mexico? Is it the Incidence of Reforms or the Growing Demand for Skills?

-M.I. Cragg and M. Epelbaum 